\title{
Removal of Hydrogen Sulfide in Biogas From Wastewater Treatment Sludge by Real Scale Biotrickling Filtration Desulfurization Process
}

Sema Arıman ( $\nabla$ sema.ariman@samsun.edu.tr)

Samsun University https://orcid.org/0000-0001-7201-9243

\section{Serdar Koyuncu}

Konya Metropolitan Municipality

\section{Research Article}

Keywords: Biogas, Anaerobic sludge digester, Biological desulfurization, Removal of hydrogen sulphide

Posted Date: August 17th, 2021

DOl: https://doi.org/10.21203/rs.3.rs-696411/v1

License: @ (i) This work is licensed under a Creative Commons Attribution 4.0 International License. Read Full License 


\section{Abstract}

High sulfur content in excess sludge impacts the production of biomethane during anaerobic digestion, meanwhile leads to hydrogen sulfide $\left(\mathrm{H}_{2} \mathrm{~S}\right)$ formation in biogas. This study aims to reveal the efficiency of the realscale Biotrickling Filtration Process (BTF) in the removal of $\mathrm{H}_{2} \mathrm{~S}$ in the biogas formed in the anaerobic digester. The biogas was produced by stabilization of the treatment sludges formed in the processes of Urban Wastewater Treatment Plant with mesophilic anaerobic sludge digesters. It was determined that the anaerobic stabilization unit of the treatment plant was operated efficiently and the biogas with a high flow $(18,123-21,383$ $\mathrm{m} 3 /$ day) was formed during the operation of the plant. The $\mathrm{H}_{2} \mathrm{~S}$ concentration in the biogas at the inlet of the BTF was 3,632 ppmv on average (2,900-4,400 ppmv) and 16 ppmv at the outlet. The elimination capacity of the system reached a maximum of $52.71 \mathrm{gH}_{2} \mathrm{~S} \mathrm{~m}-3 \mathrm{~h}-1$. As a result, a real scale BTF unit was found to provide a sufficient removal efficiency (97.84-99.90\%) for $\mathrm{H}_{2} \mathrm{~S}$ in the biogas.

\section{Introduction}

Anaerobic digestion (AD) is commonly used in the treatment of organic waste, such as agricultural waste, sewage sludge and organic form of municipal solid waste. During this process, approximately $95 \%$ of the organic matter and $95 \%$ of the energy present in the substrate are restrained in the biogas. (Guerrero et al. 2015). The biogas produced through anaerobic digestion is an environment friendly and important renewable energy resource (Oztürk 2007; Khoshnevisan et al. 2018). The produced biogas can be burned directly in combined heat and energy conversion plants and can be used as transportation fuel. Biogas is produced through anaerobic digestion of the treatment sludge originating from the wastewater treatment plants. The most important ingredients in the biogas produced by the digestion of the treatment sludges through anaerobic processes are: $60-70 \%$ methane $\left(\mathrm{CH}_{4}\right), 30-35 \%$ carbondioxide $\left(\mathrm{CO}_{2}\right), 1-2 \%$ hydrogen sulphide $\left(\mathrm{H}_{2} \mathrm{~S}\right)$ and $0.3-3 \%$ other gases (Al Mamun and Shuichi Torii 2015; Rulkens 2008). The components of the biogas can vary depending on the used substrate for the production (Rasi et al. 2007). If the substrate used for biogas production contains sulphur, the formation of hydrogen sulphide $\left(\mathrm{H}_{2} \mathrm{~S}\right)$ is inevitable. (Chaiprapat et al. 2015, Dumont 2015).

The concentration of $\mathrm{H}_{2} \mathrm{~S}$ in biogas varies from a few hundred to ten thousand ppm depending on the amount of bioavailable sulfur compounds in the feedstock and the outcome of the competition among sulfate-reducing bacteria, acetogens and methanogens for the organic substrates (Stams et al. 2005). The presence of high concentration of $\mathrm{H}_{2} \mathrm{~S}$ causes corosion on the equipment and increases the maintenance costs. Especially, due to the corrosive effect on the gas engines, engine life is shortened, the service/maintenance costs increase, and the conversion of biogas to electricity decreases. (Rasi et al. 2011). For this reason, $\mathrm{H}_{2} \mathrm{~S}$ must be removed from the produced biogas. By the removal of the $\mathrm{H}_{2} \mathrm{~S}$, higher quality biogas is produced increasing electricity

production and extending the life of equipment used. In addition, $\mathrm{H}_{2} \mathrm{~S}$ should be removed in terms of health and security (Deublein and Steinhauser 2008).

Actually, $\mathrm{H}_{2} \mathrm{~S}$ is produced under anaerobic conditions because sulphate $\left(\mathrm{SO}_{2}{ }^{4-}\right)$ acts as an electron acceptor while organic compounds are decomposed biologically. $\mathrm{H}_{2} \mathrm{~S}$ is produced by anaerobic degradation of sulfur-containing compounds (mainly proteins) and reduction of anionic species (especially $\mathrm{SO}_{4}{ }^{2-}$ ) in the 
feedstock of the digester (Ramos et al. 2013). Kuenen (1975) proposed the mechanism of HS removal that occurs through a series of physico-chemical processes and biological reactions, summarized by Equation (1)(4) below.

\section{(a) $\mathrm{H}_{2} \mathrm{~S}_{(\mathrm{g})}$ dissolution in water $\mathrm{H}_{2} \mathrm{~S}_{(\mathrm{g})} \rightarrow \mathrm{H}_{2} \mathrm{~S}_{a q}$}

(b) $\mathrm{H}_{2} \mathrm{~S}$ biological oxidation to $\mathrm{SO}_{4}{ }^{2-}$

$$
\mathrm{H}_{2} \mathrm{~S}_{(\mathrm{aq})}+2 \mathrm{O}_{2(\mathrm{~g})} \rightarrow 2 \mathrm{H}^{+}+\mathrm{SO}_{4}^{2-}
$$

(c) $\mathrm{H}_{2} \mathrm{~S}$ biological oxidation to $\mathrm{S}_{(\mathrm{s})}$

$$
2 \mathrm{H}_{2} \mathrm{~S}_{(a q)}+\mathrm{O}_{2(\mathrm{~g})} \rightarrow 2 \mathrm{~S}_{(\mathrm{s})}^{0}+2 \mathrm{H}_{2} \mathrm{O}
$$

(d) $\mathrm{S}_{(\mathrm{s})}$ biological oxidation to $\mathrm{SO}_{4}{ }^{2-}$

$$
2 \mathrm{~S}_{(s)}^{0}+3 \mathrm{O}_{2(\mathrm{~g})}+2 \mathrm{H}_{2} \mathrm{O} \rightarrow 2 \mathrm{H}^{+}+\mathrm{SO}_{4}^{-2}
$$

All of the processes lead to changes in terms of $\mathrm{pH}$, dissolved oxygen and oxidation-reduction potential (ORP), which can be used to follow and control process performance (Janssen et al. 1998). There are also other reactions that have been reported, including non-biological oxidation of $\mathrm{H}_{2} \mathrm{~S}$ to thio-sulphate and the further biological oxidation of thio-sulphate to sulphuric acid (Fortuny et al. 2011).

For the removal of $\mathrm{H}_{2} \mathrm{~S}$ in biogas; solid phase adsorption, liquid phase absorption, membrane seperation, chemical, biological, and thermal methods are used (Abatzoglou and Boivin 2009; Wellinger and Linberg 2000; Rasi et al. 2011; Lin 2013; Angelidaki et al. 2018; Diaz et al. 2011; Peluso et al. 2019). The biological desulphurisation of biogas can be performed in additional units mainly using bio-filters and bio-trickling filters during digestion process and by applying microaerobic conditions directly in anaerobic digestors (Ramos et al. 2013). This biological desulphurisation treatment method for the cleaning the contaminated biogas is a relatively new trend and is of great interest. On the other hand other gas desulphurisation methods have high operation costs and produce wastes that must be disposed. Biological desulphurisation method is economically more advantageous and more environment friendly than the other methods. Biological desulphurisation of biogas takes place under low temperature and pressure and can proceed with limited reactive consumption or no reactive consumption (Alverez 2003; Syed et al. 2006). This treatment method is also more useful because the gas stream contains biodegradable or biconvertable compounds (Gabriel and Deshusses 2003; Tomas et al. 2009).

In bioreactor systems, first hydrogen sulfide in the gas phase is dissolved into sulfur oxidizing bacteria (SOB) containing microbial media, followed by the oxidization of hydrogen sulfide by bacteria with oxygen in the liquid phase (Duan et al. 2006; Park et al. 1999). High elimination capacity and stability in the presence of severe operating conditions are required for bioreactor systems to be able to apply biological methods for the removal of high-strength hydrogen sulfide in a biogas stream. A large number of biodesulfurization processes are present, such as the biofilter processes (Rodriguez et al. 2014; Montebello et al. 2014; Ramos and Fdz-Polanco 2014), the bioscrubber processes (Hansen and Rindel 2000; Valero et al. 2019), and the process using 
headspace of the digesters (headspace process) (Ramos and Fdz-Polanco 2012). The differences between these systems are the phase of the biomass (suspended or fixed), the state of the liquid phase (flowing or stationary) and the state of having or not having a carrier material (Ramirez et al. 2009). BTF, the waste air stream passes through a bed which is packed and which has pollutant-degrading organisms immobilized in the form of biofilms. The contaminant either passes from gas phase to liquid phase and later to the biofilm, or directly from gas phase to the biofilm, where it is eventually degraded biologically to harmless compounds (Gabriel and Deshusses 2003). The usage areas of BTF are large-scale gas applications to control and other odorous emissions from WWTPs and other industries (Khanongnuch et al. 2019). Its major advantages are having low operation cost, requiring low-energy and chemicals and having high removal efficiencies (REs), mostly above $99 \%$ (Aita et al. 2016). Thus, the aim of the present study is to eliminate $\mathrm{H}_{2} \mathrm{~S}$ from biogas generated in Konya advanced biological urban wastewater treatment plant sludge through anaerobic processes with the use of real scale biotrickling filtration desulphurisation method.

\section{Material And Methods}

\subsection{Real-Scale Biotrickling Filtration (BTF) Process}

This study performed at Konya advanced biological urban wastewater treatment plant with an equivalent population of 1,000,000 and a flow rate of $20000 \mathrm{~m}^{3} /$ day. BTF was used for the purification of $\mathrm{H}_{2} \mathrm{~S}$ in the biogas collected at the anaerobic digester output used for sludge stabilization. In this process, the $\mathrm{H}_{2} \mathrm{~S}$ is removed from biogas and biogas is cooled to condense the moisture in it and the condensate is disposed. Biogas collected from anaerobic sludge digesters is transferred to the feeding chamber at the bottom of the closed tower where the BTF unit is located. The biogas moves from bottom to the top and in the tower that contains layers of polypropylene media filling circles (Table 1) where desulphurisation occurs. A complexed culture of sulfur oxidizing bacteria (SOB) dominated by Acidithiobacillus thiooxidans acclimated from activated sludge was used as the bacterial strain and a biofilm was formed. In order to supply the substrate for the SOB, treated wastewater was feeded to the feeding chamber at the bottom of the tower. The feeding water was passed through heat exchangers to adjust the temperature to $35-36^{\circ} \mathrm{C}$ and it was sprayed to the media material from the top of the tower. Some authors reported for similar sulfide-oxidizing microorganisms, an optimum growth temperature at around $30{ }^{\circ} \mathrm{C}$ (Ravichandra et al. 2006; Sanchez et al. 2014). Operation of $\mathrm{H}_{2} \mathrm{~S}$ biofiltration reactors report $100 \%$ removal efficiency at $30-50{ }^{\circ} \mathrm{C}$, but only $20 \%$ at temperatures below $10{ }^{\circ} \mathrm{C}$ (Yang and Allen 1994). At the entrance point of the desulphurisation unit 1.5-3.5\% air was added to the biogas.

In this process, $\mathrm{O}_{2} / \mathrm{H}_{2} \mathrm{~S}$ ratio was $2 / 1$. The end product of oxidation, sulfate (high $\mathrm{O}_{2} / \mathrm{H}_{2} \mathrm{~S}$ ratio in biofilm) or elemental sulfur (low $\mathrm{O}_{2} / \mathrm{H}_{2} \mathrm{~S}$ ratio), should vary depending on the availability of oxygen for microorganisms in the bioreactor. If the oxygen is more than the stoichiometric requirement, the formation of elemental sulfur decreases (Buisman et al. 1991). The treated biogas was passed through cooling units to decrease the temperature and moisture before it was feeded into the gas conversion engines. The filtrate collected at the bottom of the unit was discharged into the sulphur fertiliser tank. The sludge layer accumulated on the polypropylene material was disposed from the system by back-washing. The flow diagram of Biotrickling Filtration process is given in Figure 1.

Table 1. BTP media material characteristics 


\begin{tabular}{|ll|}
\hline Material & Polypropylen (PP) \\
\hline Shape & Perforated rings \\
\hline Size $(\mathrm{D} 1-\mathrm{D} 2 / \mathrm{L})(\mathrm{mm})$ & $100-90 / 50-35$ \\
\hline Colour & Black \\
\hline Porozity & $92 \%$ \\
\hline Specific surface area $\left(\mathrm{m}^{2} / \mathrm{m}^{3}\right)$ & 140 \\
\hline Weight $(\mathrm{gr} / \mathrm{adet})$ & 39 \\
\hline Pieces per unit volume $\left(\mathrm{pieces} / \mathrm{m}^{3}\right)$ & 2080 \\
\hline Density $\left(\mathrm{kg} / \mathrm{m}^{3}\right)$ & 80 \\
\hline
\end{tabular}

\subsection{BTF Operational Conditions}

Real scale BDP design criteria are given in Table 2. The produced biogas consits of $65 \%$ methane $\left(\mathrm{CH}_{4}\right), 34 \%$ carbondioxide $\left(\mathrm{CO}_{2}\right)$, and $1 \% \mathrm{H}_{2} \mathrm{~S}$ and other gasses. The process was designed for biogas average temperature to be $30^{\circ} \mathrm{C}$ and the dilution water average temperature to be $15^{\circ} \mathrm{C}$.

Table 2. Biological desulphurisation process design criteria

\begin{tabular}{lll} 
Parameter & Unit & Value \\
\hline Flow rate & $\mathrm{Nm}^{3} /$ hour & 1,500 \\
\hline Inlet $\mathrm{H}_{2} \mathrm{~S}$ concentration & $\mathrm{ppm}$ & 5,000 \\
\hline Outlet $\mathrm{H}_{2} \mathrm{~S}$ concentration & $\mathrm{ppm}$ & 200 \\
\hline Inlet biogas temperature & ${ }^{\circ} \mathrm{C}$ & 30 \\
\hline Inlet biogas temperature & ${ }^{\circ} \mathrm{C}$ & 5 \\
\hline Biogas pressure & $\mathrm{mbar}$ & 15 \\
\hline Methane $\left(\mathrm{CH}_{4}\right)$ & $\%$ & 65 \\
\hline Carbondioxide $\left(\mathrm{CO}_{2}\right)$ & $\%$ & 34 \\
\hline Nitrogen $\left(\mathrm{N}_{2}\right)$ & $\%$ & 7 \\
\hline Oxygen $\left(\mathrm{O}_{2}\right)$ & $\%$ & 2 \\
\hline
\end{tabular}

\subsection{Monitoring and Analytical Methods}

The $\mathrm{pH}$ is an important parameter affecting the process efficiency and the system was operated in the $\mathrm{pH}$ range of 1.5-3.5.The optimum $\mathrm{pH}$ should be in the range of 2-3.5 for activities of sulphate oxidising Acidithiobacillus thiooxidans bacteria (Syed et al. 2004; Montebello 2013; Rodriguez et al. 2014). Kim and Deshusses (2005) reported that the biological activity of microorganisms was inhibited due to the low $\mathrm{pH}$ and high sulfate content 
(at pH 2 the sulfate content in the water was 1,900 ppm). In order to monitor and control of the environment conditions of sulphur bacteria taking active role in the system, full otomation (SCADA) system was used. In this biological desulphurisation process; biogas flow meter, air flow meter, circulation liquid flow meter, $\mathrm{pH}$ and temperature measurement devices, dilution (addition) liquid indicators, biogas oxygen analysis system, sulphur removal tower, tank level indicator, gas detector, pressure indicator, and other instruments were used. In order to compare the ability of biofilters on the same basis, the elimination capacity (EC) was used. It represents the ability in removing pollutants in gaseous form compared to the incoming pollutant mass, expressed as the mass of pollutant removed per unit time per bed volume. The parameters used in this study to describe the operating conditions and for the determination of the removal performances are given in Table 3.

Table 3. Process control parameters used in this study

\begin{tabular}{lll}
\hline & Formula & Nomenclature \\
\hline Loading rate $\left(\mathrm{gH}_{2} \mathrm{~S} \mathrm{~m}^{-3} \mathrm{~h}^{-1}\right)$ & $L R=\frac{Q}{V} C_{\text {in }}$ & $\begin{array}{l}\mathrm{C}_{\text {in }} \text { = concentration of } \mathrm{H}_{2} \mathrm{~S} \text { in gas } \\
\text { entering biofilter }\left(\mathrm{ppm}_{\mathrm{v}}\right)\end{array}$ \\
Elimination capacity $\left(\mathrm{gH}_{2} \mathrm{~S} \mathrm{~m}^{-3} \mathrm{~h}^{-1}\right)$ & $E C=\frac{Q}{V}\left(C_{\text {in }}-C_{\text {out }}\right)$ & $\begin{array}{l}\mathrm{C}_{\text {out }} \text { = concentration of } \mathrm{H}_{2} \mathrm{~S} \text { in gas } \\
\text { exiting biofilter }\left(\mathrm{ppm}_{\mathrm{v}}\right)\end{array}$ \\
Removal efficiency (\%) & $R E(\%)=\frac{\left(C_{\text {in }}-C_{\text {out }}\right)}{C_{\text {in }}} \times 100$ & $\begin{array}{l}\text { Q: Flow rate of mixed gas entering } \\
\text { biofilter }\left(\mathrm{m}^{3} / \mathrm{h}\right)\end{array}$ \\
Empty Bed Residence Time (min) & $E B R T=\frac{V}{Q}$ & V: Empty packed bed volume $\left(\mathrm{m}^{3}\right)$ \\
\hline
\end{tabular}

$\mathrm{H}_{2} \mathrm{~S}$ removal efficiency of real scale BTF system was monitored for twelve months between January 2017 and December 2017 and the performance of the process was evaluated. During this period, the flow rate of biogas produced in the anaerobic sludge digesters, minimum, maximum, and average values of $\mathrm{H}_{2} \mathrm{~S}$ level in the biogas and at the process outlet were monitored on a monthly basis to determine the $\mathrm{H}_{2} \mathrm{~S}$ removal efficiency of the process. During this study, biogas flow was measured by flow meter (Drager) and $\mathrm{H}_{2} \mathrm{~S}$ concentration was measured by $\mathrm{H}_{2} \mathrm{~S}$ measurement tubes (Rea) and analyzed by colourmatic method (TS EN 1231: 2000).

\section{Results And Discussion}

\subsection{Anaerobic Digester and Biogas Production}

The flow rate of biogas and the $\mathrm{H}_{2} \mathrm{~S}$ concentration in the biogas were measured for the efficient process operation. The operational parameters of the mesophilic anaerobic sludge digester $(\mathrm{pH}$, organic loading rate, sludge feeding rate, ambient temperature, volatile organic acid concentration, sludge retention time) during the operation of the biological desulphurisation process, were given in Table 4. The characteristics of sludge at the inlet and outlet of sludge digester (total solid material, chemical oxygen demand, protein, alcalinity) were given in Table 5. The most important indicator showing the efficient operation of the anaerobic sludge digesters is the biogas production. During the working period, the flow rate of biogas produced in anaerobic sludge digesters varied between 18,123-21,383 $\mathrm{m}^{3} /$ day and an average of 19,519 $\mathrm{m}^{3} /$ day (Table 6) (Figure 2). However, the 
range of percentage composition of the biogas produced from $A D$ processes is dependent upon several factors including the digestibility of organic matter, digestion kinetics, digester retention time, and the digestion temperature (Dobre et al. 2014).

Table 4. Anaerobic sludge digester operation parameters

\begin{tabular}{|ll|}
\hline Parameters & Value \\
\hline $\mathrm{pH}$ & $7.3-8.1$ \\
\hline Organic loading ratio (OLR) $\left(\mathrm{kg} / \mathrm{gün} / \mathrm{m}^{3}\right)$ & $1.2-1.5$ \\
\hline Sludge feed flow $\left(\mathrm{m}^{3} / \mathrm{h}\right)$ & $16-17$ \\
\hline Temperature $\left({ }^{\circ} \mathrm{C}\right)$ & $36-41$ \\
\hline Volatile fatty acid (VFA)/Alkalinity & $0.02-0.08$ \\
\hline Sludge Retention Time (SRT) (day) & 17 \\
\hline
\end{tabular}

Table 5. Sludge characteristics in anaerobic sludge digester

\begin{tabular}{|lll|}
\hline Parameters & Feed Sludge & Anaerobic sludge digester outlet \\
\hline TS $(\mathrm{mg} / \mathrm{L})$ & $25,100-37,500$ & $21,000-30,100$ \\
\hline COD $(\mathrm{mg} / \mathrm{L})$ & $19,100-32,000$ & $9,400-19,000$ \\
\hline TKN (mg/L) & $1,500-4,150$ & $1,300-4,700$ \\
\hline Protein (mg/L) & $11,000-23,100$ & $7,400-22,000$ \\
\hline Alkalinity (mg/L) & $720-1300$ & $2,450-3,900$ \\
\hline VFA (mg/L) & $450-1450$ & $60-230$ \\
\hline
\end{tabular}

\subsection{Hydrogen Sulfide Removal from Biogas}

The inlet $\mathrm{H}_{2} \mathrm{~S}$ concentration was routinely measured per day to assess the variation of the inlet $\mathrm{H}_{2} \mathrm{~S}$ load. $\mathrm{H}_{2} \mathrm{~S}$ concentration of biogas at the inlet of the BTF unit varied between 2,900-4,400 ppm and an average of 3,632 ppm (Table 6). The $\mathrm{H}_{2} \mathrm{~S}$ concentration in biogas is consistent with the literature (Jenicek et al. 2008; Charnnok et al. 2013; Reddy et al. 2019;). The biogas generated in anaerobic digestion facilities in WWTPs contains average concentrations of $\mathrm{H}_{2} \mathrm{~S}$ in the range from 0.1 to $0.5 \mathrm{vol}$. \% (1000-5000 ppmv) (Walsh et al. 1998). At the outlet of the BTF process, $\mathrm{H}_{2} \mathrm{~S}$ concentration varied between 4-63 ppm and an average of $16 \mathrm{ppm}$. (Figure 3). No relation was determined between the biogas flow rate produced in anaerobic sludge digester and the $\mathrm{H}_{2} \mathrm{~S}$ concentration in the biogas. It is thought that $\mathrm{H}_{2} \mathrm{~S}$ is produced depending on the other factors (protein and sulphate concentrations in wastewater, etc.) completely independent from the produced biogas quantity.

Table 6. Operation parameters for BTF 


\begin{tabular}{|c|c|c|c|c|c|c|c|}
\hline Time & $\begin{array}{l}\text { Biogas } \\
\left(\mathrm{m}^{3} / \mathrm{d}\right)\end{array}$ & $\begin{array}{l}\text { Inlet }\left[\mathrm{H}_{2} \mathrm{~S}\right]_{\text {biogas }} \\
\left(\mathrm{ppm}_{\mathrm{v}}\right)\end{array}$ & $\begin{array}{l}\text { Outlet }\left[\mathrm{H}_{2} \mathrm{~S}\right]_{\text {biogas }} \\
\left(\mathrm{ppm}_{\mathrm{v}}\right)\end{array}$ & $\begin{array}{l}\mathrm{H}_{2} \mathrm{~S} \text { LR } \\
\left(\mathrm{gH}_{2} \mathrm{~S}\right. \\
\left.\mathrm{m}^{-3} \mathrm{~h}^{-1}\right)\end{array}$ & $\begin{array}{l}\text { EBRT } \\
(\min )\end{array}$ & $\begin{array}{l}\mathrm{EC} \\
\left(\mathrm{gH}_{2} \mathrm{~S}\right. \\
\left.\mathrm{m}^{-3} \mathrm{~h}^{-1}\right)\end{array}$ & $\begin{array}{l}\mathrm{H}_{2} \mathrm{~S} \\
\text { removal } \\
\text { efficiency } \\
\text { (\%) }\end{array}$ \\
\hline
\end{tabular}

\begin{tabular}{llllllll}
\hline January & 19,627 & 2,923 & 63 & 33.47 & 7.34 & 32.74 & 97.84 \\
\hline February & 19,581 & 3,233 & 14 & 36.93 & 7.35 & 36.77 & 99.57 \\
\hline March & 19,673 & 3,200 & 23 & 36.72 & 7.32 & 36.46 & 99.28 \\
\hline April & 19,714 & 2,900 & 12 & 33.35 & 7.30 & 33.21 & 99,59 \\
\hline May & 19,526 & 3,253 & 17 & 37.05 & 7.37 & 36.86 & 99.48 \\
\hline June & 18,233 & 4,103 & 6 & 43.64 & 7.90 & 43.58 & 99.85 \\
\hline July & 18,123 & 4,000 & 20 & 42.29 & 7.95 & 42.08 & 99.50 \\
\hline August & 18,683 & 3,900 & 4 & 42.50 & 7.71 & 42.46 & 99.90 \\
\hline September & 20,583 & 4,400 & 10 & 52.83 & 7.00 & 52.71 & 99.77 \\
\hline October & 21,383 & 4,133 & 4 & 51.55 & 6.73 & 51.50 & 99.90 \\
\hline November & 18,617 & 3,433 & 11 & 37.28 & 7.73 & 37.16 & 99.68 \\
\hline December & 20,483 & 4,100 & 12 & 48.99 & 7.03 & 48.85 & 99.71 \\
\hline Avearge & 19,519 & 3,632 & 16 & 41.38 & 7.39 & 41.20 & 99.55 \\
\hline
\end{tabular}

Since the produced biogas is used in the production of electrical energy, $\mathrm{H}_{2} \mathrm{~S}$ needs to be removed due to the corrosive effect of $\mathrm{H}_{2} \mathrm{~S}$ on gas engines and other auxiliary equipment. For this reason, $\mathrm{H}_{2} \mathrm{~S}$ concentration should be reduced up to the limit value ( $\leq 260 \mathrm{ppm}$ ) determined for gas engines before biogas is given to gas engines. The recommended level of $\mathrm{H}_{2} \mathrm{~S}$ in the produced biogas is in the range of 0.02 to $0.05 \%(\mathrm{w} / \mathrm{w})(200$ to $500 \mathrm{ppm})$ while $\mathrm{H}_{2} \mathrm{~S}$-free biogas is more desirable (Rodriguez al. 2014). During the working period, the $\mathrm{H}_{2} \mathrm{~S}$ removal efficiency ranged between $97.84-99.90 \%$ and an average of $99.55 \%$. (Table 6). In January 2017, when the performance of the process started to be monitored, $\mathrm{H}_{2} \mathrm{~S}$ removal efficiency was observed to be $97.8 \%$ and increased during operation to $99 \%$ (Figure 4). It was determined that the $\mathrm{H}_{2} \mathrm{~S}$ concentration at the outlet of BTF process was well below the determined limit value.

The elimination capacity (EC) and RE as functions of the load supplied to the system were analyzed for BTF reactor. Figure 4 shows the removal efficiency and elimination capacity of $\mathrm{H}_{2} \mathrm{~S}$ monthly. EC changes as a function of EBRT and LR values. In BTF process, EBRT values were between 6.3-7.95 min, LR values were between 33.35-52.83 $\mathrm{g} \mathrm{H}_{2} \mathrm{~S} \mathrm{~m}^{-3} \mathrm{~h}^{-1}$, EC values were between 33.21-51.71 $\mathrm{g} \mathrm{H}_{2} \mathrm{~S} \mathrm{~m}^{-3} \mathrm{~h}^{-1}$ (Figure 4). The average $\mathrm{H}_{2} \mathrm{~S}$ removal was $99.9 \%$ at EBRT of 7.39 min (i.e., a LR of $41.38 \mathrm{~g} \mathrm{H}_{2} \mathrm{~S} \mathrm{~m}^{-3} \mathrm{~h}^{-1}$ ). In addition, the elimination capacity and $\mathrm{H}_{2} \mathrm{~S}$ removal efficiency of this study BTF proces performance well when compared to the previous studies (Table 7). 
Tablo 7. Comparison of the performance of BTF reported in the literature on the treatment of biogas polluted by $\mathrm{H}_{2} \mathrm{~S}$ 


\begin{tabular}{|c|c|c|c|c|c|c|c|}
\hline Scale & Type bed & $\begin{array}{l}\text { Packed } \\
\text { Bed } \\
\text { volume }\end{array}$ & $\begin{array}{l}\text { Inlet } \\
{\left[\mathrm{H}_{2} \mathrm{~S}\right]} \\
\text { (ppmv) }\end{array}$ & $\begin{array}{l}\text { Gas } \\
\text { residence } \\
\text { time } \\
\text { (EBRT) }\end{array}$ & $\begin{array}{l}\text { Elimination } \\
\text { capacity } \\
\text { (EC) } \\
\mathrm{g} \mathrm{H}_{2} \mathrm{~S} \mathrm{~m}^{-3} \\
\mathrm{~h}^{-1}\end{array}$ & $\begin{array}{l}\mathrm{H}_{2} \mathrm{~S} \\
\mathrm{RE} \\
(\%)\end{array}$ & Reference \\
\hline $\begin{array}{l}\text { Lab- } \\
\text { scale }\end{array}$ & $\begin{array}{l}\text { Polypropylene pall } \\
\text { rings }\end{array}$ & $1 \mathrm{~L}$ & 170 & $36 \mathrm{~s}$ & 20 & 100 & $\begin{array}{l}\text { Cox and } \\
\text { Deshusses } \\
2001\end{array}$ \\
\hline $\begin{array}{l}\text { Lab- } \\
\text { scale }\end{array}$ & HD-QPAC & $2 \mathrm{~L}$ & 2000 & $3 \mathrm{~min}$ & 55 & 99 & $\begin{array}{l}\text { Maestre } \\
\text { et al. } 2010\end{array}$ \\
\hline $\begin{array}{l}\text { Lab- } \\
\text { scale }\end{array}$ & $\begin{array}{l}\text { Polypropylene } \\
\text { rings }\end{array}$ & $1 \mathrm{~L}$ & 5415 & $5.5 \mathrm{~min}$ & 89.4 & 100 & $\begin{array}{l}\text { Zhou et al. } \\
2015\end{array}$ \\
\hline $\begin{array}{l}\text { Lab- } \\
\text { scale } \\
\text { (bench) }\end{array}$ & Calgon AP460 & $6.4 \mathrm{~L}$ & $20-100$ & 4-16 min & 22.1 & 90 & $\begin{array}{l}\text { Duan et al. } \\
2005\end{array}$ \\
\hline $\begin{array}{l}\text { Lab- } \\
\text { scale } \\
\text { (pilot) }\end{array}$ & Plastic pall rings & $5.15 \mathrm{~m}^{3}$ & $\begin{array}{l}1954 \pm \\
454\end{array}$ & $180 \mathrm{~min}$ & $50 \pm 11$ & 94 & $\begin{array}{l}\text { Rodriguez et al. } \\
2014\end{array}$ \\
\hline $\begin{array}{l}\text { Lab- } \\
\text { scale }\end{array}$ & HD Q-PAC & $2.15 \mathrm{~L}$ & $\begin{array}{l}2000- \\
8000\end{array}$ & $180 \mathrm{~s}$ & 50 & 100 & $\begin{array}{l}\text { Montebello } \\
\text { et al. } 2010\end{array}$ \\
\hline $\begin{array}{l}\text { Lab- } \\
\text { scale } \\
\text { (pilot) }\end{array}$ & $\begin{array}{l}\text { Metallic Pall rings } \\
\text { (AISI 316) }\end{array}$ & $2 \mathrm{~L}$ & 2000 & $180 \mathrm{~s}$ & $100-140$ & $\begin{array}{l}95- \\
100\end{array}$ & $\begin{array}{l}\text { Montebello } \\
\text { et al. } 2012\end{array}$ \\
\hline $\begin{array}{l}\text { Lab- } \\
\text { scale }\end{array}$ & $\begin{array}{l}\text { Polypropylene Pall } \\
\text { rings }\end{array}$ & $2 \mathrm{~L}$ & 2000 & $131 \mathrm{~s}$ & $50-100$ & $\begin{array}{l}35- \\
100\end{array}$ & $\begin{array}{l}\text { Montebello et } \\
\text { al. } 2013\end{array}$ \\
\hline $\begin{array}{l}\text { Lab- } \\
\text { scale }\end{array}$ & Metallic Pall rings & $2.4 \mathrm{~L}$ & $\begin{array}{l}2000- \\
10000\end{array}$ & $130 \mathrm{~min}$ & $100-140$ & $70-80$ & $\begin{array}{l}\text { Montebello et } \\
\text { al. } 2014\end{array}$ \\
\hline $\begin{array}{l}\text { Lab- } \\
\text { scale }\end{array}$ & HS- Q-PAC & $2.15 \mathrm{~L}$ & $\begin{array}{l}900- \\
10000\end{array}$ & $180 \mathrm{~s}$ & 200 & 84 & $\begin{array}{l}\text { Fortuny et al. } \\
2008\end{array}$ \\
\hline $\begin{array}{l}\text { Lab- } \\
\text { scale }\end{array}$ & HD-Q-PAC & $2 \mathrm{~L}$ & 2000 & $167-180$ & 84 & $\begin{array}{l}97 \\
\pm 0.3\end{array}$ & $\begin{array}{l}\text { Fortuny et al. } \\
2011\end{array}$ \\
\hline $\begin{array}{l}\text { Lab- } \\
\text { scale }\end{array}$ & $\begin{array}{l}\text { Polypropylene pall } \\
\text { rings }\end{array}$ & $2.4 \mathrm{~L}$ & $\begin{array}{l}850- \\
8500\end{array}$ & $2.4-3.5$ & $99.8-130$ & 99 & $\begin{array}{l}\text { Fernandez et al. } \\
2014\end{array}$ \\
\hline $\begin{array}{l}\text { Lab- } \\
\text { scale } \\
\text { (pilot) }\end{array}$ & $\begin{array}{l}\text { Polyurethane } \\
\text { foam }\end{array}$ & $\begin{array}{l}600 \mathrm{~m}^{2} \\
\mathrm{~m}^{-3} \\
\text { surface } \\
\text { area }\end{array}$ & $5-25$ & $15-40 \mathrm{~s}$ & $15-95$ & 99 & $\begin{array}{l}\text { Gabriel and } \\
\text { Deshusses } \\
2003\end{array}$ \\
\hline
\end{tabular}


and 35

$\mathrm{kg} \mathrm{m}^{-3}$

\begin{tabular}{|c|c|c|c|c|c|c|c|}
\hline $\begin{array}{l}\text { Lab- } \\
\text { scale } \\
\text { (pilot) }\end{array}$ & $\begin{array}{l}\text { Ceramic granules } \\
\text { Volcanic rocks }\end{array}$ & 1177 L & $\begin{array}{l}2.84 \pm \\
1.76 \\
\mathrm{mg} / \mathrm{m}^{3}\end{array}$ & $5-20 s$ & $2.82-2.85$ & $\begin{array}{l}60- \\
100\end{array}$ & Li et al. 2012 \\
\hline $\begin{array}{l}\text { Full- } \\
\text { scale }\end{array}$ & $\begin{array}{l}\text { Polypropylene pall } \\
\text { rings }\end{array}$ & - & 3000 & $180 \mathrm{~s}$ & 170 & 90 & $\begin{array}{l}\text { Tomas et al. } \\
2009\end{array}$ \\
\hline $\begin{array}{l}\text { Lab- } \\
\text { scale } \\
\text { (pilot) }\end{array}$ & BioSulfidEx & $2.21 \mathrm{~m}^{3}$ & $\begin{array}{l}500- \\
600\end{array}$ & 84 & 32.3 & 98 & $\begin{array}{l}\text { Naegele et al. } \\
2013\end{array}$ \\
\hline $\begin{array}{l}\text { Lab- } \\
\text { scale }\end{array}$ & $\begin{array}{l}\text { Polyethylene } \\
\text { (HDPE) }\end{array}$ & $1 \mathrm{~L}$ & $0-2040$ & 120 & 78.57 & 100 & $\begin{array}{l}\text { Vikromvarasiri } \\
\text { et al. } 2017\end{array}$ \\
\hline $\begin{array}{l}\text { Lab- } \\
\text { scale } \\
\text { (pilot) }\end{array}$ & $\begin{array}{l}\text { Commercial } \\
\text { polyester fibers }\end{array}$ & $12 \mathrm{~L}$ & $\begin{array}{l}1000- \\
4000\end{array}$ & $\begin{array}{l}10.29-72 \\
\min \end{array}$ & 14.58 & 100 & $\begin{array}{l}\text { Soreanu et al., } \\
2008\end{array}$ \\
\hline $\begin{array}{l}\text { Lab- } \\
\text { scale }\end{array}$ & Schist & $7.85 \mathrm{~L}$ & 1100 & $300 \mathrm{~s}$ & 30.3 & 100 & $\begin{array}{l}\text { Jabera et al. } \\
2017\end{array}$ \\
\hline $\begin{array}{l}\text { Lab- } \\
\text { scale }\end{array}$ & $\begin{array}{l}\text { 3D-printed } \\
\text { honeycomb } \\
\text { monolith }\end{array}$ & $0.2 \mathrm{~L}$ & 2000 & $41 \mathrm{~s}$ & 122 & 95 & Qiu et al. 2017 \\
\hline $\begin{array}{l}\text { Lab- } \\
\text { scale }\end{array}$ & $\begin{array}{l}\text { K1 packing } \\
\text { material }\end{array}$ & $0.5 \mathrm{~L}$ & 200 & $\begin{array}{l}40-100 \\
s\end{array}$ & - & $\begin{array}{l}92.27 \\
\pm \\
10.30\end{array}$ & $\begin{array}{l}\text { Zhuo et al. } \\
2019\end{array}$ \\
\hline $\begin{array}{l}\text { Lab- } \\
\text { scale }\end{array}$ & HDPE Plastics & $1 \mathrm{~L}$ & 2000 & $120 \mathrm{~s}$ & 82.98 & 99.5 & $\begin{array}{l}\text { Juntranapaporn } \\
\text { et al. } 2019\end{array}$ \\
\hline $\begin{array}{l}\text { Lab- } \\
\text { scale } \\
\text { (Semi- } \\
\text { pilot ) }\end{array}$ & $\begin{array}{l}\text { Polypropylene Pall } \\
\text { rings }\end{array}$ & $4000 \mathrm{~L}$ & 2000 & $15 \mathrm{~min}$ & 29.5 & $\begin{array}{l}94.6- \\
99.6\end{array}$ & $\begin{array}{l}\text { Reddy et al. } \\
2019\end{array}$ \\
\hline $\begin{array}{l}\text { Lab- } \\
\text { scale }\end{array}$ & Bamboo charcoal & $643 \mathrm{~L}$ & $5-20$ & $\begin{array}{l}10.9- \\
28.9 \mathrm{~s}\end{array}$ & 6.58 & 99.8 & Chen et al. 2019 \\
\hline $\begin{array}{l}\text { Lab- } \\
\text { scale }\end{array}$ & $\begin{array}{l}\text { Polyurethane } \\
\text { foam }\end{array}$ & $3 \mathrm{~L}$ & $\begin{array}{l}1246- \\
305\end{array}$ & $1.6 \mathrm{~min}$ & 98 & $95-99$ & $\begin{array}{l}\text { Tayar et al. } \\
2019\end{array}$ \\
\hline $\begin{array}{l}\text { Lab- } \\
\text { scale }\end{array}$ & $\begin{array}{l}\text { Polypropylene pall } \\
\text { rings }\end{array}$ & $2.8 \mathrm{~L}$ & 2000 & $118 \mathrm{~s}$ & 120 & 100 & $\begin{array}{l}\text { Lopez et al. } \\
2019\end{array}$ \\
\hline $\begin{array}{l}\text { Pilot } \\
\text { scale }\end{array}$ & $\begin{array}{l}\text { Polypropylene } \\
\text { spheres }\end{array}$ & $440 \mathrm{~L}$ & $\begin{array}{l}1.2 \\
\mathrm{~g} / \mathrm{m}^{3}\end{array}$ & $40 \mathrm{~s}$ & 122 & 100 & Xia et al. 2019 \\
\hline $\begin{array}{l}\text { Lab- } \\
\text { scale }\end{array}$ & PUF cubes & $3 L$ & 4000 & $3 \mathrm{~min}$ & 113.5 & 97 & $\begin{array}{l}\text { Watsuntorn et } \\
\text { al. (in press) }\end{array}$ \\
\hline
\end{tabular}




\subsection{Microbial community}

In effective removal of $\mathrm{H}_{2} \mathrm{~S}$, microorganisms have important roles. Sulfide oxidizing bacteria (SOB) are gram negatives which can use sulfide and thiosulfate as an energy source. Due to their ability to tolerate a pH swing between 1.5 and 3.5, SOB Acidithiobacillus thiooxidans was found to be a major microorganism group in our biofilter in the present study. This bacterium is thought to be an ideal inoculum for the biofiltration of $\mathrm{H}_{2} \mathrm{~S}$ in biogas and it is the most acidophilic SOB (Aita et al. 2016; Ramirez et al. 2016). It has a pH range between 0.5 and 5.5 and an optimum at pH 2-3 for growth (Wang et al. 2019). In this technology, the headspace of anaerobic digesters functions as a $\mathrm{H}_{2} \mathrm{~S}$ abatement unit that causes the development of various microaerophilic SOBs such as Acidithiobacillus sp., Arcobacter sp., Sulfuricuvum sp., Sulfurimonas sp., Thiobacillus sp., Thiofaba sp. and Thiomonas sp. in case of the development of limited amount of $\mathrm{O}_{2}$ (Diaz et al. 2011; Kobayashi et al. 2012; Rodri Guez et al. 2012). This result is similar to the results of Lee et al. (2006) which showed that in degradation of $\mathrm{H}_{2} \mathrm{~S}$, Thiobacillus thiooxidans proliferating between $\mathrm{pH} 2$ to 0.5 and Acidithiobacillus thiooxidansAZ11 could grow at $\mathrm{pH}$ as low as 0.2 . It was reported that it was still possible to reach high removal efficiencies of $99.9 \%$, $98.0 \%$, and $94.0 \%$, respectively. In acidic conditions, Acidithiobacillus sp. was reported to reach an $\mathrm{H}_{2} \mathrm{~S}$ elimination capability (EC) of 113 (Aita et al. 2016), 150.3 (Charnnok et al. 2013) and $113.5 \mathrm{gH}_{2} \mathrm{~S} / \mathrm{m}^{3} / \mathrm{h}$ (Chaiprapat et al. 2011). Our EC $35 \mathrm{gH}_{2} \mathrm{~S} / \mathrm{m}^{3} / \mathrm{h}$ at the condition for $\mathrm{H}_{2} \mathrm{~S}$ removal is similar to those reported in the aforementioned Acidithiobacillus sp. predominant experiments. $\mathrm{pH}$ of the recirculating fluid was found to decrease rapidly and vary between 1.5 and 3.5. It can be seen from the results that the SOB culture in the BTF reactor has already adapted to the condition of inlet $\mathrm{H}_{2} \mathrm{~S}$ concentration and eliminated $\mathrm{H}_{2} \mathrm{~S}$ in biogas.

\section{Conclusion}

In this study, the removal of $\mathrm{H}_{2} \mathrm{~S}$ from the biogas that was produced at real scale anaerobic sludge digester by BTF process was investigated. Average biogas flow rate produced in mesophilic anaerobic sludge digester varied between $18,123-21,383 \mathrm{~m}^{3} /$ day and $\mathrm{H}_{2} \mathrm{~S}$ concentration vaeried between $2,923-4,400 \mathrm{ppm}_{\mathrm{v}}$. It was observed that the $\mathrm{H}_{2} \mathrm{~S}$ concentration in the produced biogas is completely independent from the biogas flow rate. The removal of high concentartions of $\mathrm{H}_{2} \mathrm{~S}$ in biogas was accomplished by real scale BTF process with SOB bacteria (Acidithiobacillus Thiooxidans) which active at acidic environment (pH 1.5-3.5.). BTF process was operated at; $\mathrm{pH}: 1.5-3.5, \mathrm{O}_{2} / \mathrm{H}_{2} \mathrm{~S}: 1 / 2$, EBRT:6.3-7.95 minutes, LR:33.35-52.83 $\mathrm{g} \mathrm{H}_{2} \mathrm{~S} / \mathrm{m}^{-3} \mathrm{~h}^{-1}$. The $\mathrm{H}_{2} \mathrm{~S}$ removal efficiency (RE) varied in the range of \%97.84-99.90 and $\mathrm{H}_{2} \mathrm{~S}$ elimination capacity (EC) varied in the range of 33.21-52.71 $\mathrm{gH}_{2} \mathrm{~S} \mathrm{~m}^{-3} \mathrm{~h}^{-1}$. The process efficiency was found to be independent of inlet $\mathrm{H}_{2} \mathrm{~S}$ concentration. The average $\mathrm{H}_{2} \mathrm{~S}$ values in biogas desulphurized by BTF process ranged between 4-63 ppm. As a result, BTF process regardless of the biogas flow and inlet $\mathrm{H}_{2} \mathrm{~S}$ concentration was found to be an effective and efficient process for the removal of $\mathrm{H}_{2} \mathrm{~S}$ from biogas produced in the real scale anaerobic sludge digester.

\section{Declarations}


Ethics approval: Not applicable

Consent of Participate: Not applicable

Availability of data and materials: Not applicable

Competing interests: We declare that they have no conflict of interest.

Funding: No funding was received for conducting this study.

Code availability (software application or custom code): Not applicable

Consent for publication: Not applicable

Authors' contributions: All authors contributed to the study conception and design. Material preparation and data collection was done by SK. The study of analysis was performed by SA. The first draft of the manuscript was written by SA and SK commented on previous versions of the manuscript. All authors read and approved the final manuscript.

\section{Acknowledgments}

We sincerely thank General Directorate of Water and Sewerage Administration (KOSKI) of Konya Metropolitan Municipality for providing technical and financial support to this study.

\section{References}

Abatzoglou N. and Boivin S (2009) A review of biogas purification processes. Biofuels Bioprod Bioref 3:42-71.

Aita BC, Mayer FD, Muratt DT, Brondani M, Pujol SB, Denardi LB, Ronaldo Hoffmann R, Silveira DD (2016) Biofiltration of $\mathrm{H}_{2} \mathrm{~S}$-rich biogas using Acidithiobacillus thiooxidans. Clean Technologies and Environmental Policy 18:689-703.

Al Mamun MR, Shuichi Torii S (2015) Removal of Hydrogen Sulfide $\left(\mathrm{H}_{2} \mathrm{~S}\right)$ from Biogas Using Zero-Valent Iron. Journal of Clean Energy Technologies 3:6.

Alvarez MJ (2003) Biomethanization of the organic fraction of municipal solid wastes, IWA Publishing UK.

Angelidaki I, Treu L, Tsapekos P. Luo G, Campanaro S, Wenzel H, Kougias PG (2018) Biogas upgrading and utilization-current status and perspectives. Biotechnol Adv 36: 452-466.

Chaiprapat S, Charnnok B, Kantachote D, Sung S (2015) Bio-desulfurization of biogas using acidic biotrickling filter with dissolved oxygen in step feed recirculation. Bioresour Technol 179:429-435.

Chaiprapat S, Mardthing R, Kantachote D, Karnchanawong S (2011) Removal of hydrogen sulfide by complete aerobic oxidation in acidic biofiltration. Process Biochem 46:344-352.

Charnnok B, Suksaroj T, Boonswang P, Chaiprapat S (2013) Oxidation of hydrogen sulfide in biogas using dissolved oxygen in the extreme acidic biofiltration operation. Bioresource Technology 131:492-499. 
Chena YQ, Xie L, Caic WF, Wu JW (2019) Pilot-scale study using biotrickling filter to remove H2S from sewage lift station: Experiment and CFD simulation. Biochemical Engineering Journal 144:177-184.

Cox HHJ, Deshusses AM (2001) Co-treatment of $\mathrm{H}_{2} \mathrm{~S}$ and toluene in a biotrickling filter. Chemical Engineering Journal 87(1):-101-110.

Deublein D, Steinhauser A (2008) Biogas from Waste and Renewable Resources: An Introduction. Wiley-VCH Weinheim.

Diaz I, Perez SI, Ferrero EM, Fdz-Polanco M (2011) Effect of oxygen dosing point and mixing on the microaerobic removal of hydrogen sulphide in sludge digesters. Bioresour Technol 102:3768-3775.

Dobre P, Nicolae F, Matei F (2014) Main factors affecting biogas production-an overview. Rom Biotech Lett 19(3):9283-9296.

Dumont $\mathrm{E}$ (2015) $\mathrm{H}_{2} \mathrm{~S}$ removal from biogas using bioreactors: a review. Internatıonal Journal of Energy and Environment 6(5):479-498.

Fernandez M, Ramirez M, Gomez JM, Cantero D (2014) Biogas biodesulfurization in an anoxic biotrickling filter packed with open-pore polyurethane foam. Journal of Hazardous Material 264:529-535.

Fortuny M, Baeza JA, Deshusses MA, Gamisans X, Casas C, Lafuente J, Gabriel D (2008) Biological sweetening of energygases mimics in biotrickling filters. Chemosphere 71:10-17.

Fortuny M, Gamisans X, Deshusses MA, Lafuente J, Casas C, Gabriel D (2011) Operational aspects of the desulfurization process of energy gases mimics in biotrickling filters. Water Research 45:5665-567.

Gabriel D, Deshusses MA (2003) Retrofitting existing chemical scrubbers to biotrickling filters for H2S emission control. Proc. Natl. Acad. Sci. 100(11):6308-6312.

Guerrero L, Montalvo S, Huilinir C, Campos JL, Barahona A, Borja R (2015) Advances in the biological removal of sulphides from aqueous phase in anaerobic processes: A review. Environ Rev 24:84-100.

Hansen NG, Rindel K (2000) Bioscrubbing, an effective and economic solution to odour control at wastewater treatment plant. Water Science and Technology 41:155-164.

Jabera MB, Couverta A, Amranea A, Cloireca LP, Dumont E (2017) Hydrogen sulfide removal from a biogas mimic by biofiltration under anoxic conditions. Journal of Environmental Chemical Engineering 5:5617-5623.

Janssen AJH, Meijer S, Bontsema J, Lettinga G (1998) Application of the redox potential for controlling a sulfide oxidizing bioreactor. Biotechnol Bioeng 60:147-155.

Jenicek P, Keclik F, Maca J, Bindzar J (2008) Use of microaerobic conditions for the improvement of anaerobic digestion of solid wastes P. Water Science \& Technology 58 (7):1491-1496

Juntranapaporn J, Vikromvarasiri N, Soralump C, Pisutpaisal N (2019) Hydrogen sulfide removal from biogas in biotrickling filter system inoculated with Paracoccus pantotrophus. International Journal of Hydrogen Energy 
44(56): 29554-29560.

Khanongnuch R, Di Capua F, Lakaniem AM, Rene ER, Lens PNL (2019) $\mathrm{H}_{2} \mathrm{~S}$ removal and microbial community composition in an anoxic biotrickling filter under autotrophic and mixotrophic conditions. J Hazard Mater 367:397-406.

Khoshnevisan B, Tsapekos P, Alvarado-Morales M, Angelidaki I (2018) Process performance and modelling of anaerobic digestion using. Bioresource Technology 247:486-495.

Kim S, Deshusses MA (2005) Understanding the limits of $\mathrm{H}_{2} \mathrm{~S}$ degrading biotrickling filters using a differential biotrickling filter. Chem Eng J 113:119-126.

Kobayashi T, Li YY, Kubota K, Harada H, Maeda T, Yu HQ (2012) Characterization of sulfide-oxidizing microbial mats developed inside a full-scale anaerobic digester employing biological desulfurization. Appl Microbiol Biotechnol 93:847-857.

Kuenen JG (1975) Colourless sulphur bacteria and their role in the sulphur cycle. Plant Soil 43:49-76.

Lee EY, Lee NY, Cho KS, Ryu HW (2006) Removal of hydrogen sulfide by sulfate-resistant Acidithiobacillus thiooxidans AZ11. J Biosci Bioeng 101:309-314.

Li J, Ye G, Sun D, Sun G, Zeng X, Xu J, Liang S (2012) Performances of two biotrickling filters in treating H2Scontaining waste gases and analysis of corresponding bacterial communities by pyrosequencing. Appl. Microbiol. Biotechnol 95:1633-1641.

Lin WC, ChenYP, Tseng CP (2013) Pilot-scale chemical-biological system for efficient $\mathrm{H}_{2} \mathrm{~S}$ removal from biogas. Bioresource Technology 135:283-291.

Lopez LR, Mora M, Baeza JA, Lafuente J, Gabriel D (2019) Titrimetry as a tool for the on-line monitoring of biological activity in a desulfurizing biotrickling filter under aerobic conditions Process Safety and Environmental Protection 124:151-157.

Maestre JP, Rovira R, Alvarez-Hornos FJ, Fortuny M, Lafuente J, Gamisans X, Gabriel D (2010) Bacterial community analysis of a gas-phase biotrickling filter for biogas mimics desulfurization through the rRNA approach. Chemosphere 80:872-880.

Montebello AM (2013) Aerobic Biotrickling filtration for biogas desulfurization. Environmental science and technology PhD Thesis, Universitat Auto`noma de Barcelona, Bellaterra.

Montebello AM, Baeza M, Lafuente J, Gabriel D (2010) Monitoring and performance of a desulphurizing biotrickling filter with an integrated continuous gas/liquid flow analyser. Chem Eng J 165(2):500-507.

Montebello AM, Bezerra T, Rovira R, Rago L, Lafuente J, Gamisans X, Campoy S, Baeza M. Gabriel D (2013) Operational aspects, $\mathrm{pH}$ transition and microbial shifts of a $\mathrm{H}_{2} \mathrm{~S}$ desulfurizing biotrickling filter with random packing material. Chemosphere 93:2675-2682. 
Montebello AM, Fernandez M, Almenglo F, Ramirez M, Cantero D, Baeza M, Gabriel D (2012) Simultaneous, methylmercaptan and hydrogen sulfide removal in the desulfurization of biogas in aerobic and anoxic biotrickling filters. Chem Eng J 200-202:237-246.

Montebelloa AM, Mora M, Luis R, Lopez LR, Bezerraa T, Gamisans, X, Lafuentea J, Baezac M, Gabriel D (2014) Aerobic desulfurization of biogas by acidic biotrickling filtration in a randomly packed reactor. Journal of Hazardous Materials 280:200-208.

Naegele $\mathrm{H}$, Lindner J, Merkle W, Lemmer A, Jungbluth T, Bogenrieder C (2013) Effects of temperature, $\mathrm{pH}$ and $\mathrm{O}_{2}$ on the removal of hydrogen sulfide from biogas by external biological desulfurization in a full scale fixed-bed trickling bioreactor (FBTB). International Journal Agriculture Biology Enginnering 6(1):69-81.

Oztürk I (2007) Anaerobik arıtma ve uygulamaları, Su Vakfı Yayınları, İstanbul.

Peluso A, Gargiulo N, Aprea P, Pepe F, Caputo D (2019) Nanoporous Materials as $\mathrm{H}_{2} \mathrm{~S}$ Adsorbents for Biogas Purification: a Review. Separation \& Purification Reviews 48:78-89.

Qiu X, Marc A, Deshusses MA (2017) Performance of a monolith biotrickling filter treating high concentrations of $\mathrm{H}_{2} \mathrm{~S}$ from mimic biogas and elemental sulfur plugging control using pigging. Chemosphere 186:790-797.

Ramirez M, Gomez JM, Aroca G, Domingo CD (2009) Removal of hydrogen sulfide by immobilized Thiobacillus thioparus in a biotrickling filter packed with polyurethane foam. Bioresource Technology 100:4989-4995.

Ramos I, Fdz-Polanco M (2012) The role of the headspace in hydrogen sulfide removal during microaerobic digestion of sludge. Water Science Technology 66(10):2258-2264.

Ramos I, Fdz-Polanco M (2014) Microaerobic control of biogas sulphide content during sewage sludge digestion by using biogas production and hydrogen sulphide concentration. Chem Eng J 250:303-311.

Ramos I, Perez R, Fdz-Polanco M (2013) Microaerobic desulphurisation unit: a new biological system for the removal of $\mathrm{H}_{2} \mathrm{~S}$ from biogas. Bioresour Technol 142:633-640.

Rasi S, Lantela J, Rintala J (2011) Trace compounds affecting biogas energy utilisation-A review. Energy Convers Manag 52:3369-3375.

Rasi S, Veijanen A, Rintala J (2007) Trace compounds of biogas from different biogas production plants. Energy 32:1375-1380.

Ravichandra PM., Ramakrishna A, Gangagni R, Annapurna J (2006) Sulfide oxidation in a batch fluidized bed bioreactor using immobilized cells of isolated Thiobacillus sp. (IICT-SOB-DAIRY-201) as biocatalyst. J Eng Sci Technol 1(1): 21-30.

Reddy CN, Baeb S, Mina B (2019) Biological removal of $\mathrm{H}_{2} \mathrm{~S}$ gas in a semi-pilot scale biotrickling filter: Optimization of various parameters for efficient removal at high loading rates and low $\mathrm{pH}$ conditions. Bioresource Technology 285:121328. 
Rodriguez E, Lopes A, Fdz-Polanco M, Stams AJM, Garcia-Encina P (2012) Molecular analysis of the biomass of a fluidized bed reactor treating synthetic vinasse at anaerobic and micro-aerobic conditions. Appl Microbiol Biotechnol 93:2181-2191. doi:10.1007/s00253-011-3529-3.

Rodriguez G, Dorado AD, Fortuny M, Gabriel D, Gamisans X (2014) Biotrickling filters for biogas sweetening: Oxygen transfer improvement for a reliable operation. Process Safety and Environmental Protection 92:261-268.

Rulkens W (2008) Sewage Sludge as a Biomass Resource for the Production of Energy: Overview and Assessment of the Various Options. Energy \& Fuels 22:9-15.

Sanchez AG, Marquez TEF, Revah S, Sagastume JMM (2014) Enrichment and cultivation of a sulfide-oxidizing bacteria consortium for its deploying in full-scale biogas desulfurization. Biomass and Bioenergy 66:460-464.

Soreanu G, Beland M, Falletta P, Edmonson K, Seto P (2008) Laboratory pilot scale study for H2S removal from biogas in an anoxic biotrickling filter. Water Sci Technol 57(2):327-344.

Stams AJM, Plugge CM, De Bok, FAM, Van Houten BHGW, Lens P, Dijkman H, Weijma J (2005) Metabolic interactions in methanogenic and sulfate-reducing bioreactors. Water Sci Technol 52:13-20.

Syed M, Soreanu G, Falletta P, Beland, M (2006) Removal of hydrogen sulfide from gas streams using biological processes - A review. Canadian Biosystems Engineering 48: 2.

Tayar SP, Guerrero, RBS, Hidalgo LF, Bevilaqua D (2019) Evaluation of Biogas Biodesulfurization Using Different Packing Materials. Chem Engineering 3(1):27.

Tomas M, Fortuny M, Lao G, Gabriel D, Lafuente J, Gamisans X (2009) Technical and economical study of a fullscale biotrickling filter for $\mathrm{H}_{2} \mathrm{~S}$ removal from biogas. Water Pract Technol 4(2):26-33.

TS EN:1231:2000 Workplace Atmospheres-Short Term Detector Tube Measurement Systems - Requirements and Test Methods.

Valeroa PS, Penya-rojaa JM, Alvarez-Hornosa FJ, Buitronb G, Gabaldona C, Quijanob G (2019) Fully aerobic bioscrubber for the desulfurization of $\mathrm{H}_{2}$ S-rich biogas. Fuel 241: 884-891.

Vikromvarasiri N, Champreda V, Boonyawanich S, Pisutpaisa N (2017) Hydrogen sulfide removal from biogas by biotrickling filter inoculated with Halothiobacillus neapolitanus Nunthaphan Vikrom. International Journal of Hydrogen Energy 42:18425-18433.

Wang R, Lin JQ, Liu XM, Pang X, Zhang CJ, Yang CL, Gao XY, Lin CM, Li YQ, Li Y., Lin JQ, Chen LX (2019) Sulfur oxidation in the acidophilic autotrophic Acidithiobacillus spp. Front Microbiol 9: 3290.

Wellinger A and Linberg A (2000) Biogas upgrading and utilization. IEA Bioenergy Task 24, Paris, France: International Energy Association.

Xia G, Zhou X, Hu J, Sun Z, Yao J, Chen D, Wang J (2019) Simultaneous removal of carbon disulfide and hydrogen sulfide from viscose fibre waste gas with a biotrickling filter in pilot scale. Journal of Cleaner Production 230:21-28. 
Yan L, Ye J, Zhang P, Xu D, Wu Y, Liu JB, Zhang HB, Fang W, Wang B, Zeng GM (2018) Hydrogen sulfide formation control and microbial competition in batch anaerobic digestion of slaughterhouse wastewater sludge: effect of initial sludge pH. Bioresour Technol 259:67-74.

Yang Y, Allen ER 1994. Biofiltration control of hydrogen sulfide. Design and operational parameters. J Air Waste Manag. 44 (7), 863-86.

Zhuoa Y, Hana Y, Qua, Q, Lia J, Zhong C, Penga D (2019) Characteristics of low H2S concentration biogas desulfurization using a biotrickling filter: Performance and modeling analysis. Bioresource Technology 280:143150.

\section{Figures}

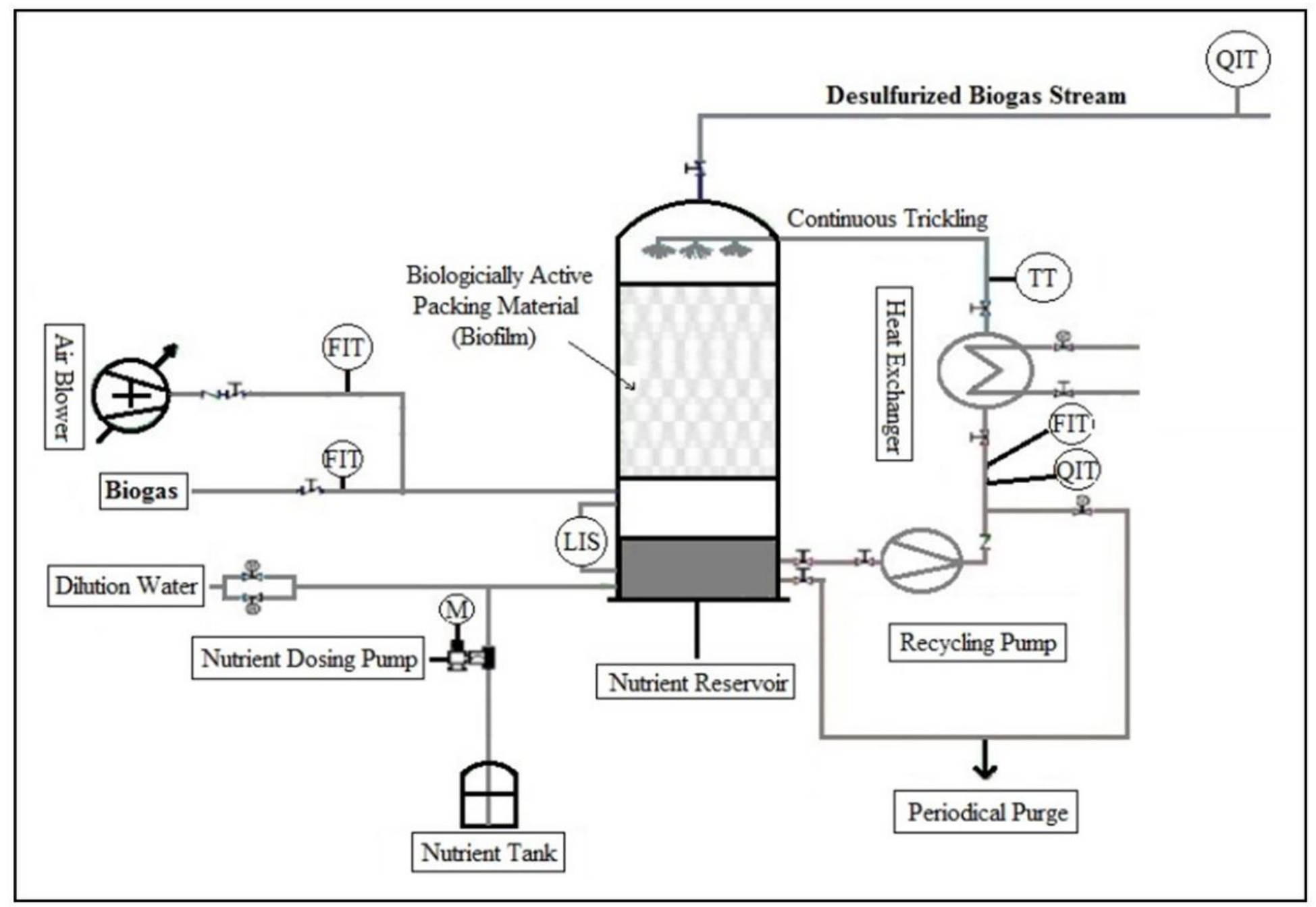

Figure 1

Real scale biotrickling filtration (BTF) process 


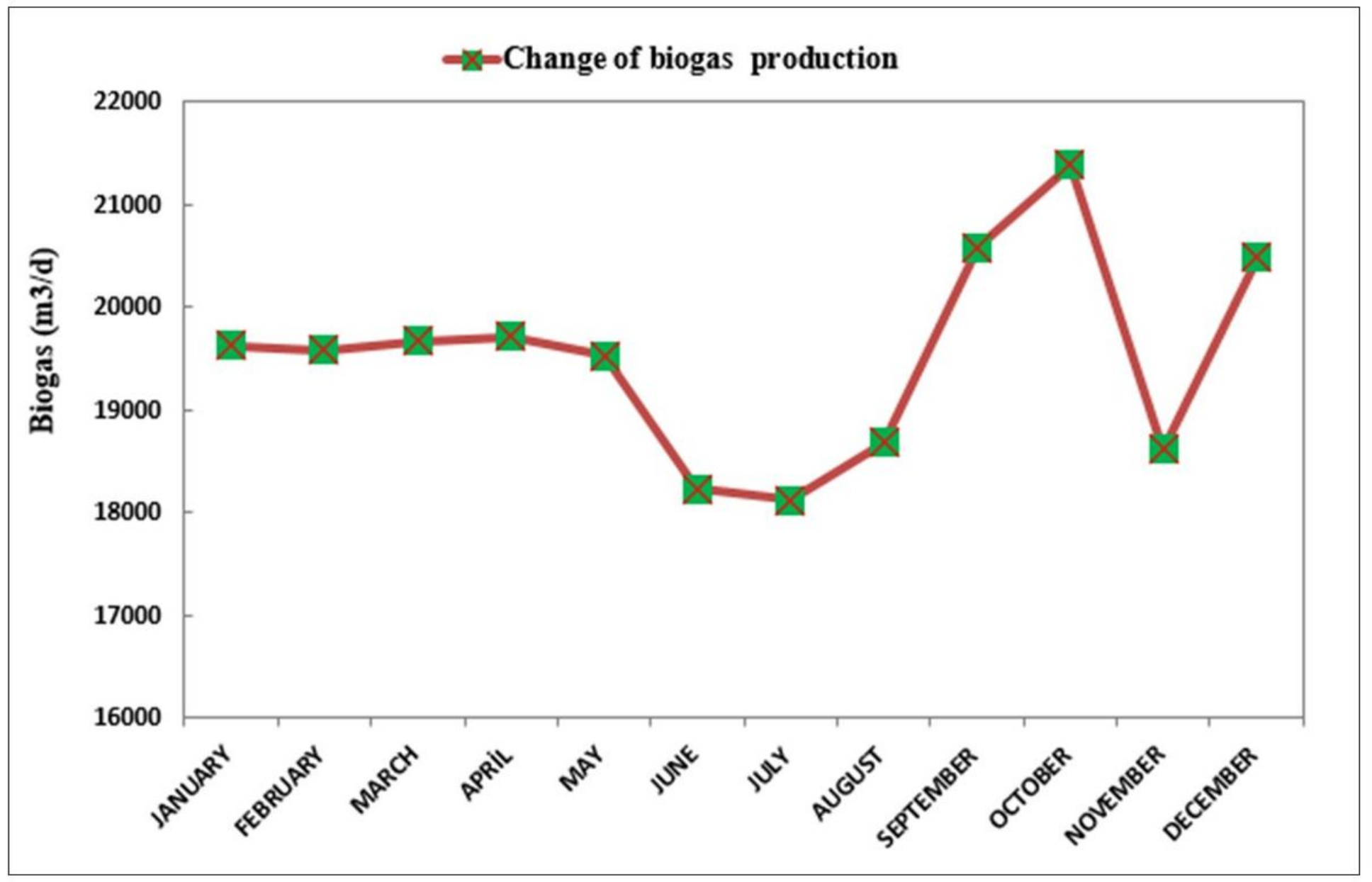

Figure 2

Variation of biogas production 


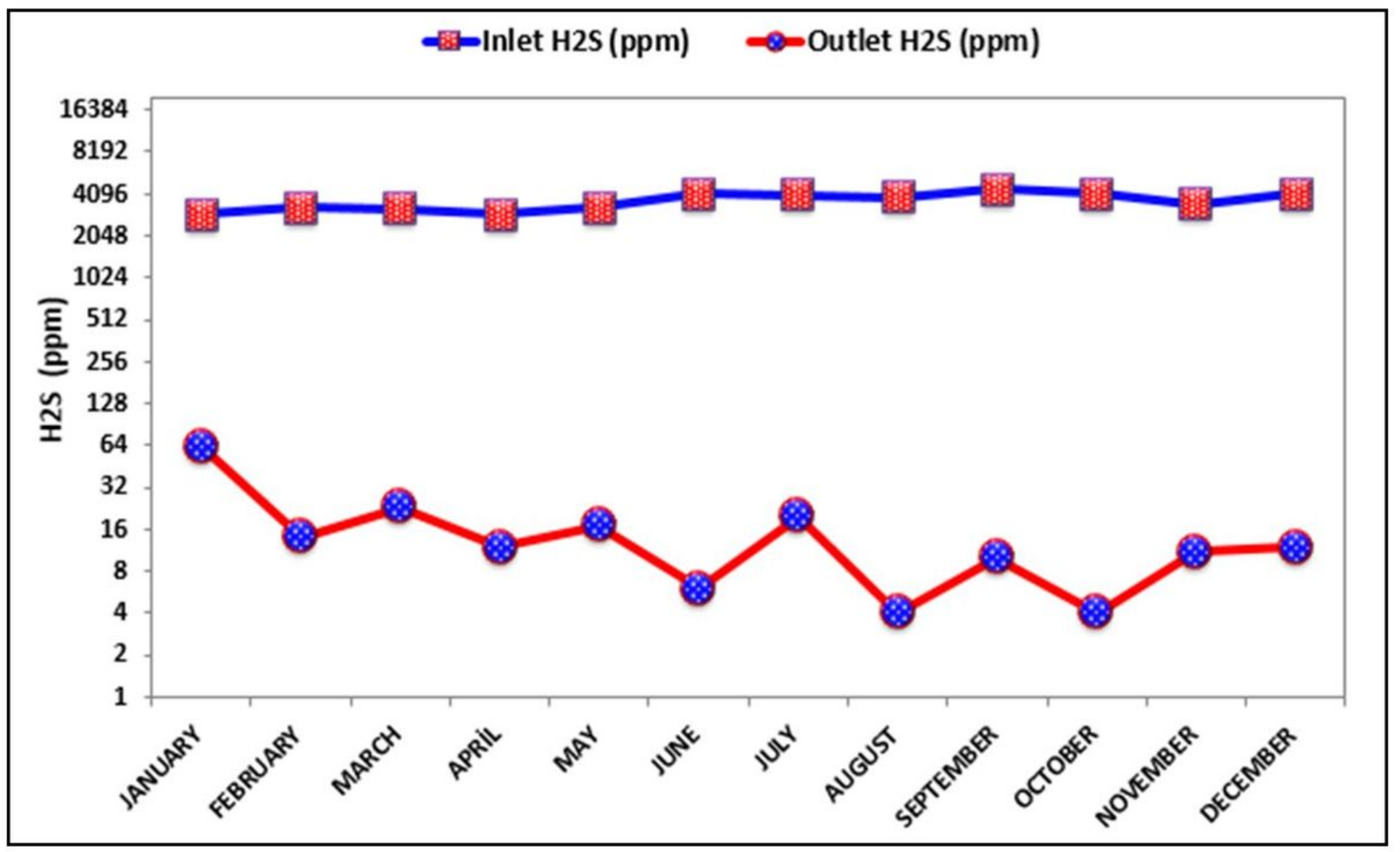

Figure 3

Variation of $\mathrm{H} 2 \mathrm{~S}$ concentration at BTF inlet and outlet 


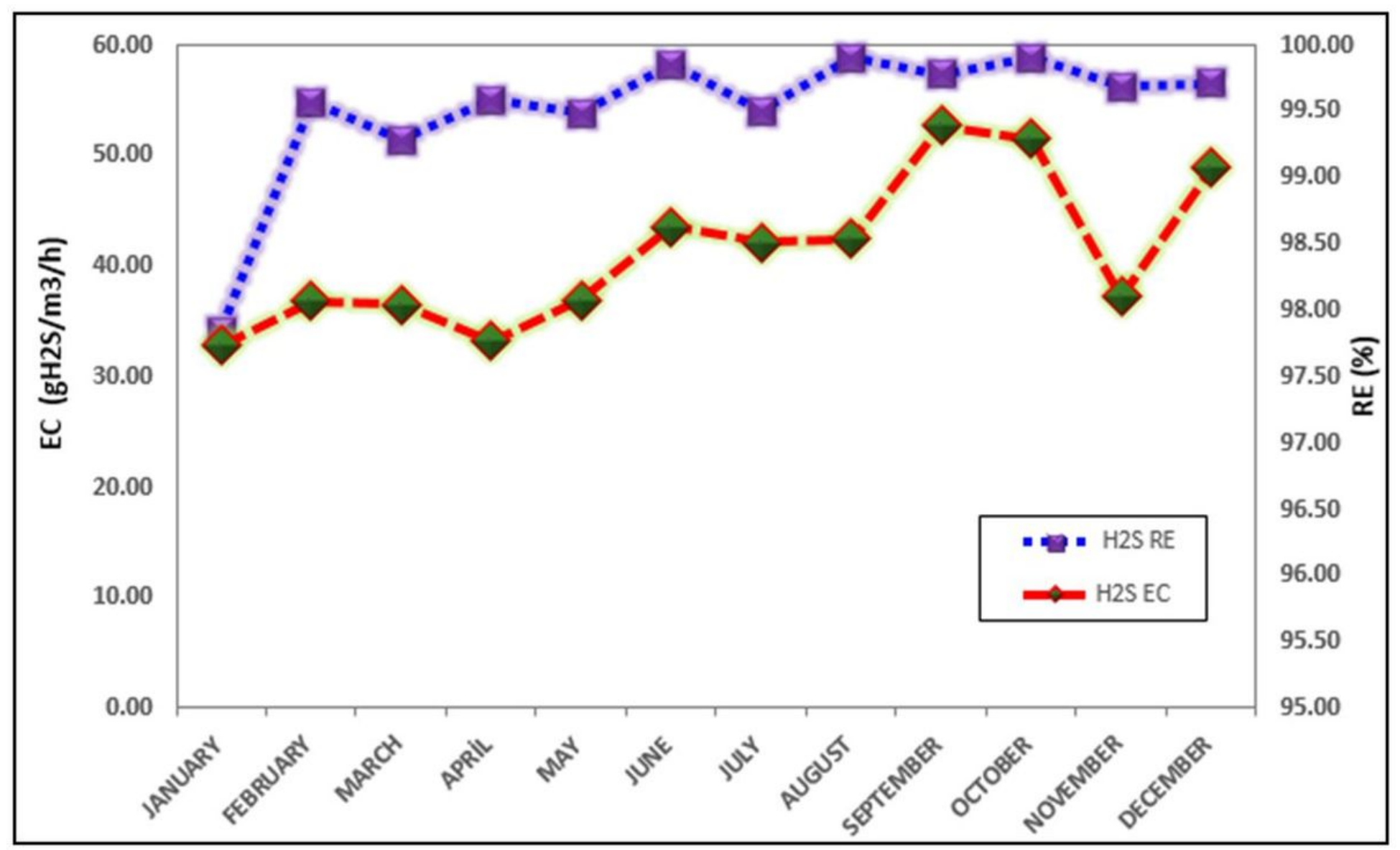

Figure 4

Variation of $\mathrm{H} 2 \mathrm{~S}$ removal efficiency and elimination capacity (EC). 